\title{
BEST PRACTICE IN BUILDING HOUSE OF WORSHIP BASED ON LOCAL WISDOM IN PALU
}

\author{
Muhammad Dachlan \\ Balai Penelitian dan Pengembangan Agama Makassar \\ Jl. AP. Pettarani No. 72 Makassar, Indonesia \\ Email: muhdaclan1970@gmail.com
}

Article received August 17 $7^{\text {th }}, 2021$; Article revised September $18^{\text {th }}, 2021$; Article approved October $22^{\text {th }}, 2021$

\begin{abstract}
The construction of houses of worship is often rejected in some regions of Indonesia. This phenomenon also occurs in Palu City. This article aims to find out how to build a house of worship based on local wisdom in Palu. By using qualitative methods, the following research results were obtained. First, the best practice of religious harmony was reflected in multicultural education, religious harmony, and cooperation in social practice. Second, the values of local wisdom that become a social tool are the culture of sintuvu (cooperation), nasorara nosabatutu (brotherhood), nasobolai (openness), libu ntodea (agreement), tonda talosi (harmony). Besides, houses of worship were also built with architectural designs with local wisdom. Third, the government's role in creating best practice of inter-religious harmony can be seen through the existence of FKUB, which has excellent programs, such as unspoiled faith for harmony, village harmony, harmony sermons, and technical guidance for traditional stakeholders.
\end{abstract}

Keywords: best practice, house of worship, local wisdom, harmony.

\section{INTRODUCTION}

I Indonesia, as a multi-religious country, is very vulnerable to conflicts, both internal and inter-religious. According to (Widjanarko, 2017), this diversity needs to be managed constructively and productively. One of them is through a structural approach and a cultural approach. An example is the establishment of houses of worship based on local wisdom (Weeks, 2015).

A cultural approach is strategic in sticking relationships between social groups, including religion (Nuruddin, 2016). If adequately explored and implemented in a planned manner, the cultural approach will become an adequate social capital in reducing conflicts between religious communities. Both approaches can be used as capital to maintain religious harmony (Widjanarko, 2017).

However, this does not mean that interreligious conflicts are over. The fact is that conflicts still occur, one of which is the conflict over the construction of houses of worship. This can be seen in several cases that have occurred; for example in 2018, there were 5 cases of attacks on houses of worship that caused a lot of damage and victims (Kumparan, 06/03/2021).

Previous researchers have carried out several studies on conflicts over the establishment of places of worship. However, there has not been much done discussing the construction of houses of worship based on local wisdom. According to Fidiyani, one of the conflict motives in the building of houses of worship is due to religious sentiments (Fidiyani, 2016; Figure, 2015).

This fact becomes an alarm for the parties concerned always to formulate strategic steps to anticipate social conflicts between religious communities. This approach is also known as the cultural approach. According to Sabara, this approach is a crucial element in bonding relationships between various social groups, including religion (Nuruddin, 2016).

The effectiveness of local culture as a social glue and cultural approach in resolving conflicts has been demonstrated by many researchers. The study of Muhammad Takdir for example, the culture of "rampak naong bringen korong" as the values of local wisdom (Takdir, 2018). Likewise, expressions from other regions such as the philosophy of life of the Bugis Makassar people such as Sipakatau, Sipakalebbi and the existence of siri' culture are the bond of religious harmony (Muhdina, 2015).

This study shows the important role of local wisdom in maintaining harmony and harmony among religious communities in Palu City through best practices in the construction of houses of worship. Departing from this 
background, the main problem formulations in this article are: 1) What is the description of the best practice for constructing houses of worship, how does local wisdom function optimally in Palu City?

\section{Dynamics of House of Worship Construction}

Basically, every religion teaches peace, brotherhood, and harmony and does not want division and enmity between one religion's adherents. However, in reality, it shows that the influence of religion on society often leads to conflict. The problem of the establishment of houses of worship is one of the motives of various anarchic actions carried out based on religion on behalf of the number of adherents of a particular religion (Adon, 2018)

Among the content of PBM that is still receiving criticism is the requirement to support a minimum of 90 users and support a minimum of 60 local people as a condition for the construction of houses of worship. Horizontal conflicts often occur between people who support and reject, suspicion among community leaders, even some people who refuse constructing houses of worship to carry out demonstrations. As in several cases that have happened, for example, in 2018 there were 5 cases of attacks on houses of worship that caused a lot of damage and victims (Aji, 2014; Putri, 2011).

\section{Local Wisdom}

Meanwhile, local wisdom is a cultural identity that can be interpreted as the cultural identity or personality of a nation. According to Rahyono, local wisdom is human intelligence possessed by certain ethnic groups obtained through community experience (Fajarini, 2014). The point is that Local wisdom reflects a principle, advice, order, norm, and behavior of our ancestors in the past which are still very urgent to be applied in managing various emerging phenomena (Muhdina, 2015).

Local wisdom is the potential, cultural and intellectual property of the Indonesian people. The values of civility and wisdom are spread evenly throughout the country, from Sabang to Merauke. Ethnic groups in Indonesia have passed down their noble values from generation to generation; cooperation, mutual respect for differences, courtesy, and fighting spirit are some of these noble values.

Central Sulawesi, the Kaili people, have an immense cultural wealth that is a unifying and driving force for the community, both in building community life and maintaining religious harmony. The most essential wisdom for the Kaili community is known as Sintuvu, namely the culture of togetherness and cooperation. From Sintuvu cult ure then gave birth to many life mottos that vary from place to time. In the city of Palu and its surroundings, there is some local knowledge known as the motto Kitorang samua basudara (reminding each other), Rasa Risi Roso Nosimpotobe (one heart). In Poso Sint uwu Maroso (strong union) in the language contains two meanings, namely Sintuwu which means "unity or unity", while maroso, which means strong unity when combined. In Morowali, it is known as Tepe Asa Moroso (United we stand), which is a strategy to reduce conflict with differences between people or groups of people from one another. These slogans invite each other to build a peaceful and harmonious society, with the principles of mutual respect, respect, and cooperation in achieving a human civilization filled with compassion.

\section{RESEARCH METHOD}

This research employed qualitative descriptive research which intended to explain social phenomena or facts related to the best practice of building houses of worship in a community based on local wisdom. This research was conducted in Palu City, Central Sulawesi.

Qualitative research in dat a collection standards acknowledged three methods: indepth interviews, observation, and document studies, both written and in the form of images and videos. Interviews were conducted by first determining informants purposively from the construction committee and administrators of houses of worship, religious leaders, community leaders, FKUB administrators, the Ministry of Religion, local governments, and parties who know the object of research. In addition to interviews, data collection was also carried out through field observations and documentation. 


\section{DISCUSSION}

\section{Socio-Cultural Religion of Palu City}

The people of Palu City are very diverse. The residents who live in this city come from various ethnic groups such as Bugis, Toraja and Mandar originating from South and West Sulawesi, Gorontalo, Manado, Javanese, Arabic, Chinese, and Kaili who are the original and largest tribes in Central Sulawesi. The original inhabitants of Palu came from 19 indigenous tribes in Central Sulawesi, namely Kaili, Kulawi, Lore, Pamona, Mori, Bungku, Saluan or Lomang, Balantak, Mamasa, Taa, Bare'e, Banggai, Buol, Toli-toli, Tomini, Dampal, Dondo, Pendau, and Dampelas. Meanwhile, the largest ethnic immigrants are Javanese, Bugis, and Makassarese (Sadiq Kawu, 2015). Meanwhile, Sidik Ibrahim's research states that the Javanese and Bugis-Makassarese, Chinese descendants are the dominant ethnic groups in Palu City. Even the people of Chinese descent are very calculated because they control economic access in the city of Palu. The facts above illustrate that people's lives in Palu City are very dynamic (Ibrahim, 2017).

If this condition is not managed properly and wisely, it could trigger horizont al disputes or conflicts. Moreover, with the rise of immigrants, the indigenous people, the Kaili tribe, are increasingly marginalized or marginalized due to economic competition (Ibrahim, 2017).

The research of Siti Hajar N Aepu et al shows that the conflict that occurred between the Bugis and the Kaili ethnic in the Manonda Inpres market in Palu was caused by the struggle for economic resources, social jealousy of the Kaili ethnic towards the Bugis ethnic. It happened because the Bugis ethnic controlled all economic spaces in the area. Economic disparities can be the cause of conflict.

This dispute led to the burning of the Manonda Inpres market in West Palu. As a result, activities in this market have stopped for some time (Rismawati, 2008). The potential for conflict in the Manonda Presidential Instruction Market in Palu City is immense, the name is economic space, especially the nuances of the market where traders and buyers meet and many problems are obtained, both in the form of small frictions, as well as significant problems that lead to conflicts with ethnic nuances ( Siti Hajar N. Aepu et al).

In general, religious life in Palu City is very harmonious and peaceful. Religious people live side by side. They blend in with each other. There is no underlying suspicion that can trigger social conflict. Ismail Pangeran confirmed this as chairman of FKUB. Even Palu City in 2019-2020 was named one of the 12 safest cities in Indonesia (Interview, 13/03/2021). In line with Ismail, Zaenal Abidin, as chairman of the Palu City MUI, also confirmed this. According to him, Palu City is relatively safe, and there has never been a religious conflict.

\section{Best Practice in Building a House of Worship (Vihara)}

The history of establishing a Buddhist house of worship in Palu City has been around for a long time. Researchers do not get enough accurate information regarding when and the founders of the early mass. However, according to Warsana's statement, one of the informants stated that in 89 the Vihara was already in Gajah Madha. In the past, the name was Temple which was founded in the 70 s. The synagogue was a long time ago. The first time I came to Palu, where all of us worshiped, but the history for sure, we also did not understand in detail. Only we know that preindependence Buddhists were already in Palu." (Interview, 04/03/2021).

While written sources of information were found, the Vihara's history in Palu City began in 1942. The name of the oldest monastery in Central Sulawesi is Magabudhi which is located at Jl. Gaja Mada no. 160 Siranindi Village, West Palu Sub-district. It was built in 1942, before independence by Phan A Lin, a native born in Parigi Moutong.

An interesting phenomenon from the history of the establishment of the Vihara in Palu City is that one of the figures who contributed significantly to the establishment of the Vihara in Palu City was a Muslim community leader named Ahmad Rumi. According to Lukito's statement that when planning the establishment of Vihara Karunadipa, Ahmad Rumi was at the forefront of providing understanding to the community, 
as well as helping to manage administrative requirements in supporting which come from the surrounding community (interviu 04/03/2021).

\section{Elements of Best Practice}

The elements of best practice in the relationship between religious adherents in Palu City, especially Buddhism, are reflected in three forms; namely education, religion and social society.

First, best practice from the educational aspect. The Karuna Dipa Foundation, which consists of kindergarten, elementary, junior high and high school/vocational schools that now exist in the center of Palu City, stands on approximately $19,000 \mathrm{~m}^{2}$. The foundation is under the management of the Palu City Buddhist Foundation, which Chinese traders historically founded. As explained by Wijaya Chandra, one of the administrators of the Karuna Dipa Foundation:

\begin{abstract}
"Through education, we have a very good relationship with brothers from other religions, whether Christian, Muslim or Hindu. The existing schools are not only intended for students from the Buddhist community, but are open to all religions. So, to ensure freedom of religion and respect for diversity, we recruit teachers of each religion, according to the presence of students, ranging from Islam, Christianity, Hinduism. Each student gets religious teaching according to their respective religions. Even in this school, there is not only diversity from a religious aspect, but also a diversity from an ethnic aspect. There are Bugis, Kaili, Javanese and Arabic (interview, 05/03/2021).
\end{abstract}

This phenomenon is very interesting and serves as a good example concerning the face of harmony amid a diverse society. As the vision, the school wants to create a school community that has multicultural insight. This vision is very appropriate among the people of Palu city, which is known as a very diverse society, both in terms of religion and ethnicity. Moreover, if the city of Palu is seen as a city that has a history of conflict, that is quite worrying, both religious and ethnic conflicts.

In addition, a multicultural education path by bringing together all existing religions and ethnicities is the main key to forming a plural society. Able to appreciate and accept the presence of others. This is important because the conflicts that occur cannot be separated from the inability of a person to accept the presence of others because they feel the most correct and safest. As a result, all others are considered unrighteous and need to be justified. In conditions like this, sometimes people impose their opinions on others, even people of other religions. One of the personal causes is a lack of insight into other people's religions because of a lack of interaction with adherents of other religions. In addition, it is fanaticism towards groups that makes him closed and rejects differences.

In this context, the role of education is very appropriate. Through education, an openminded society will be formed. With education, people tend to be rational and not easily influenced by doctrines that lead to the cult of opinions and schools of thought. On the other hand, education will always give birth to a tolerant mindset and society to accept diversity, both ethnic and religious diversity. Second, religious life. Religious life in the Buddhist community is very harmonious and full of peace. Buddhist communities with people from Islam or Christianity live side by side with a sense of brotherhood. In religious activities, the Buddhist community participates in the success of other religious holidays. As stated by the informant:

\begin{abstract}
"We respect each other with fellow believers, for example Christmas for Christians, so our children can participate in the success by dancing. Not only that, the Buddhist community also often attends Muslim holiday celebrations such as the commemoration of Isra Mikraj and Maulid" (interview, 04/03/2021).
\end{abstract}

This fact was also corroborated by Sidik, who said that there was cooperation and mutual respect between religious adherents in implementing religious holidays in Palu City. For example, during the big Muslim celebrations, Eid al-Fitr and Isra Mikraj commemorations, the organizing committee always invites people from other religions, such as Christianity and Buddhism. With the invitation, they also attended and enlivened the religious activities carried out by Muslims. On the other hand, they always invite each other to celebrate big days. We also accepted the invitation as a form of friendship and brotherhood (interview, 12/03/2021).

The harmony shown by the community in the context of religious life was fascinating. This fact shows at least two critical things. 
First, the Palu city community is a very plural and democratic society, distinguishing issues of belief and socio-cultural issues. Their presence enlivened and succeeded in the religious activities of brothers from other religions, such as Buddhists, did not diminish their faith or provoke religious conversion. However, it is more about respecting and upholding the values of brotherhood as a society that lives in a heterogeneous society.

The presence of inter-religious people in religious activities introduces religious teachings and symbols that must be respected by each other. Numerous conflicts occurred because religious adherents did not underst and the teachings and symbols of other people's religions. In the end, what usually happens is an abuse of the religious symbol, which results in conflict between religious people. Second, the above phenomenon also shows that the religious character of the Palu city community is more flexible and is more oriented to Sufism than fiqh oriented. Sufismoriented people tend to be open and not easy to blame others. It is different from the paradigm of fiqh, which tends to be black and white in judging something. If it is not halal, it is haram or makruh.

Third, cooperation in social society. One of the social actions carried out by Buddhists is helping in the construction of a mosque located next to the Vihara. As a form of solidarity, Buddhists helped build access roads to the mosque.

In addition, Buddhists, through instructions from Buddhist religious leaders, all people donate blood every holy month of Ramadan. This is in response to the scarcity of available blood due to most Muslims fasting during Ramadan. So that, it encourages the internal policy of the Buddhists to be able to meet the needs of blood bags. Other social actions, such as helping orphanages, are routinely carried out by Buddhists as a form of social responsibility and maintaining friendship and brotherhood with other people. As stated by the informant:

On their big days, such as Katina and Vesak Day, the monks come to school to get groceries from students. All students from various religions donated the goods and necessities. These necessities will eventually return to those who needed, such as the orphanage. This activity is a form of happiness in commemorating big days, such as Vesak (interview, 05/03/2021).

Religious harmony, especially amid Buddhist society, cannot be separated from two fundamental things; first, Buddhism emphasizes the soul's perfection and wisdom. Second, the ability to adapt and collaborate with Buddhists in society.

Therefore, according to Warsana, the Buddhist Pembimas of the Regional Office of the Ministry of Religion of Central Sulawesi Province (interview, 4/3/2021), none of the people dared to commit forbidden acts because their lives would be restless and haunted by guilt. This belief is an internal strength within each Buddhist to protect themselves from despicable things, including being involved in acts of violence and social conflict.

On the other hand, in the Buddhist belief, that virtue brings endless benefaction. This belief also encourages Buddhists to continue to do good and spread compassion to all beings. This process was formed starting from the education applied by Karuna Dipa by instilling multicultural education and honesty. Through this process, a wise character will be formed from an early age.

The second point is the ability to adapt and collaborate in the community. It is these two powers that appear to be very prominent to Buddhists. They do not live exclusively with other communities. They can mingle with all religions and social groups. This ability cannot be separated from the noble teachings of the Buddha, who always sees the good side of each person even though not all of the person's thoughts are correct.

"People who do good and are pleasant should be served and respected even if someone may not agree with his opinion" (Anguttara Nikaya I, 127).

One sentence in the Anguttara Nikaya is enough to describe the Buddha's attitude towards diversity of faith. Naturally, there are differences of opinion on some issues between people of faith. However, the most important thing here is whatever his belief we should judge from his attitude, whether it is virtuous or not. This is the absolute benchmark, namely kindness, not a religious label that is carried. 
Ven also emphasized the Buddha's idea of tolerance. The Dalai Lama, the spiritual leader of Tibet. He said that "Various religions have the same goal, which is to make people better. Differences between religions must be recognized, but these differences must also be understood in the context of a common purpose. So, mutual respect must develop among all religions. Each system has its value which is suitable for people of different temperaments and mentalities. In an age marked by ease of communication, we must increase our efforts to learn about each system. This does not mean that we should make all religions one, but that we should recognize the common goals of all religions and appreciate the different ways they have developed for internal improvement".

Basically, religious differences do not prevent close relations between people, either personally, family, or in groups. Interaction can be established through various things and interests. Religious harmony is a condition in which all religious groups can live together peacefully without compromising the rights and freedoms of each to adhere to and carry out their religious obligations. This is possible if every people have tolerance and understand each other's rights and freedoms.

The most important thing is the ability to appreciate and adapt to local treasures, both in oral traditions and symbols of customs. This can be seen very clearly in the form of a house of worship, Vihara Karunadipa, which is very thick with local values, a blend of Javanese, Kaili and Chinese. In this aspect, the relationship between Buddhism and art is clear. Art is a part of religious rituals. For people who have a sense of symbol language, every life experience can be religious and sacred experiences. Art Buddha is an art that contains values with the characteristics of a Buddha that can change his life into a perfect human being and behavior. In order to produce Buddhist art, it is necessary for an artist who has the vision and depth of understanding the Buddha dhamma so that his art can open up Buddhist religious horizons.

\section{Contribution of Local Wisdom Relation Between People Around the Temple}

Relations between religious people around the house of worship go harmoniously, which is marked by several things, namely, mutual assistance and respect for the implementation of religious holidays and being actively involved in the success of the celebration. The mutual help shown between religions can be seen in the social activities carried out by the sub-district government. Good interactions are also reflected in the moral and material support given to people who experience a celebration of death (interview, 12/03/2021). Meanwhile, in the implementation of significant holidays, religious people also participate in supporting the success of the event, for example, Muslims respect the celebration of Vesak Day, with the involvement of the community and Karuna Dipa school students, providing basic food for the monks (interview, 05/03/2021).

The harmonious relationship between religious communities, apart from the encouragement of high religiosity, is also inseparable from the strength of the local wisdom values of the Kaili tribe. Kaili is very famous for having local wealth, which is highly valued to this day. Included among the most domains of wisdom are sintuvu and givu customs. Sintuvu symbol izes brotherhood and unity, while givu is a tradition of traditional fines for those who violate applicable customary regulations, including those who create riot and chaos in the community (interview, 12/03/2021).

Through the tradition of gotong royong portrayed in each community, both through education and cultural formation, this, in turn, has a significant impact on everyday life. Mutual respect for the implementation of each other's worship and create mutual support and help each other in religious and social life. The awareness to accept each other due to the encouragement of Sintuvu values is very strong in society. The formation of this awareness is also strongly supported by religious and traditional leaders who continuously encourage the whole community to maintain togetherness in people's lives, regardless of skin color, ethnicity, and religion.

Inter-religious relations, especially in Palu, between Buddhists and the surrounding community, can be created very well with internal and external encouragement. Internal encouragement is in the form of Buddhist teachings that have been internalized in the souls of Buddhists. The values in question are the teachings of love and peace as the peak of achieving the soul's perfection for the Buddha. Humans can achieve good life goals and at the 
same time as a blessing life when humans have a role not only to build themselves but also to build other human beings. In this life, a person cannot be separated from mutual circumstances, interact, cooperate, help each other, etc. In Anguttara Nikaya II p. 95, Digha Nikaya III p. 233, the Buddha said:" People who pay attention to the interests of others besides his interests, is best."

In building self-principles to achieve life goals, it is realized that humans need to live together with other people. Humans cannot live alone, so humans need to build harmony, tolerance, cooperation, and others for their survival. In the process, some obligations must be fulfilled by individuals who are concerned. An example is the obligation to build harmony/tolerance, avoiding drug abuse, avoiding corrupt behavior, paying taxes on time, and others.

In addition to internal encouragement, there is also external encouragement of local customs and culture that have been institutionalized in an unwritten rule. The local culture is then known as local wisdom, which boils down to one main word/basic principle: sintuvu. Sintuvu culture is a culture of cooperation that must be upheld by all people, without exception. There is no difference between natives and immigrants.

Likewise, there is no difference in terms of religion and ethnicity. Everyone must uphold brotherhood and unity. The process of interaction that is carried out continuously will result in a social relationship. Social relations occur near or in the same area and can also occur with individuals or communities in different regions. In addition, social relations occur with the same ethnicity, race, and religion and can also occur with people of different ethnicity, race, and religion.

Social relations in society also consist of various forms, namely associative social relations or relationships and dissociative social relations or relationships. Associative social relations are more positive in cooperation, accommodation, assimilation, and acculturation. At the same time, dissociative relationships are more in four forms of competition, conflict, dispute, and others. Both patterns of social relations can be found in people's lives, both in the lives of the same community and various people's lives. Living in differences is not easy; it requires high tolerance between religious communities so that conflicts do not occur, as it is known that many conflicts occur in the name of religion. High tolerance between religious communities and well-developed social interactions will create good social relations.

\section{Values of Local Wisdom in the Kaili Ethnic Society}

The Kaili tribe is the largest ethnic group in Central Sulawesi. He has a distinctive regional language and varies according to his dialect. Currently, the tribe lives in Palu, Donggala, Sigi, Parigi Moutong, and partly on the Poso Coast. (Septiwiharti, 2020) The Kaili tribe is very famous for its wealth of local wisdom, a shared value in the community. This wealth includes language dialects that vary from one society to another. This diversity then forms division in the internal community, bound by a high sense of brotherhood and togetherness.

The local culture of the Kaili people, which is still functional to this day in caring for ethnic and religious diversity, namely Sintuvu as the primary culture, is then translated into other cultures such as Nosarara Nosabatutu, Ada Nosobolai, Libu Ntodea.

\section{Sintuvu}

Sintuvu culture represents the way of life of the Kaili tribe, who always wants harmony in society (Septiwiharti, 2020). According to Syamsuri, Sint uvu culture is the most basic and animates all other cultural values (interview, 12/03/2021). Throughout the history and concrete life of the Kaili people. Sintuvu has been known since the Tomalanggai period and developed since the kingdom (kemagauan) in the Land of Kaili, Central Sulawesi, in the 15 th century, as a culture of togetherness for the Kaili people which originates from everyday life.

From the Sintuvu culture, slogans were born, which were popularized by every leader of Palu City. For example, the expression "Masittuvu we maroso, marobangan we maris $i$ (United we are strong, together we are strong). A slogan popularized by Hidayat, the old Mayor, which means gathering all elements, there is no difference in religion and ethnicity. According to several figures, the slogan effectively maintained religious unity and harmony in Palu City (interview, 13/03/2021).

The slogan was later enshrined into a zero-kilometer monument. The monument is full of meaning and has a profound symbol. First, the bottom foundation has a giant pan with a diameter of eight. The tray is 
a place to store food as a banquet for all guests who come to visit the city of Palu. Second, the pole, which has 35 connecting irons. This is a symbol of the number of provinces throughout Indonesia. It is a unity in diversity, without any differences in race, ethnicity and religion. Third, the waiting peak has pearls as a symbol of light that emanates from a height. Forth, the main pillars represent the 1945 Constitution, Pancasila, the Unitary State of the Republic of Indonesia and Bhineka Tunggal Ika.

\section{Nosarara Nosabatutu}

Besides Sintuvu, the Kaili community has a culture of togetherness known as Nosoraa Nosabautu. Nosorara means we are brothers, and nosabatutu is a place for marbles that symbolizes togetherness and unity in one container (interview, 13/03/2021). So Haliadi stated that the nosarara nosabatutu teaching is the principle of kinship or brotherhood and the unity of the Kaili community based on blood relations. However, in its development, the nosarara nosabatutu culture has developed meaning. Brothers are limited to father and mother, but brothers include brotherhood on the broader community, who live in one community together.

According to Haliadi et al., philosophically, Nosarara Nosabatutu's expression contains a commitment to live together. Nosarara's expression is defined as "a strong fraternal commitment, close unity, mutual agreement and complete kinship". In comparison, Nosabatutu's expression has the meaning as "a commitment to a sense of shared destiny, respect and maintain existing wealth (self, nature and the environment), confidentiality and prudence or vigilance.

The Kaili principle of Nosara nosabatutu states that kinship (Nosara) and solidarity (nosabatutu) are needed to create harmony. Thus, it contains essential values that are oriented towards increasing social welfare. Nosarara nosabatutu is broad for including family values, nosarara nosabatutu also includes spiritual sentiments and preferences. One example of spiritual sentiments and preferences embodied in the concept of nosararata is the belief that one should love others as one loves one's own family, as seen in the phrase "sararata le" / "sararata ia" (our brother / sister). Spiritual values are also contained in the concept of nosarara nosabatutu.
In its implementation, Nosara Nosabatutu becomes the social glue in Palu City. As said by Zaenal Abidin, the practice of nosorara nosabatutu in the community can be seen in takziah. The community works for hand in hand. Togetherness is seen in moral and moral support to the bereaved family. That support, not only from ethnic groups and religions, but also from neighbors of different religions. There is no ethnic or religious skating. All are united in grief. Likewise, in wedding party activities, the Kaili community recognizes the term nosusa, namely grinding spices carried out by the parents of the bride and groom. Long before the event, family members and neighbors had come hand in hand to help in grinding the tempeh. The point is that Nosara Nosabatutu has become a social cohesion that can give birth to harmony and religious harmony.

\section{Ada Nosobolai (Principle of Opennees)}

Ada Nosobolai is the principle of openness for the Kaili people. This openness shows that the Kaili people are an egalitarian society, inclusive and easy-going. Ada Nosobolai is reflected in two things; first, openness to newcomers from various ethnicities and religions. Second, openness through intermarriage between the Kaili tribe and other tribes.

This culture is still the general principle to this day. According to Ahda Najamuddin, this principle causes the city of Palu to be very diverse nowadays; all religions and ethnicities can be found in Palu. Still, according to Ahda Najamuddin, the principle of openness is seen in daily attitudes and in the Kaili traditional house (kingdom), which has Legos as a symbol of acceptance to others.

\footnotetext{
"The Kaili people are very open, even though they are famous for holding on to the principles of life that come from their ancestors from generation to generation. One of the forms of openness can be seen in the Kaili traditional house. Legos are symbols and have a message of openness. Kaili people are ready to accept the presence of others. Welcoming with great respect, as long as the person is kind and also respects us." (interview, 12/03/2021).
}

Openness to others is a fundamental principle for the Kaili community. Existing data showed that Palu is a destination city for migrants from various regions to seek life in the city of Palu. The population growth from year to year continues to increase. The community is very diverse in terms of ethnicity and religion from all over Indonesia. Even economic centers such as markets are 
inhabited by many immigrants, especially the Makassar Bugis. However, there is nosobolai which simultaneously requires newcomers to adapt and respect the customs prevailing in the community. Thus, harmonious life and religious harmony can be created properly.

\section{Libu Ntodea}

Libu means consensus, while Ntodea means people. Libu Ntode is a mutual agreement that many people create after going through a process of deliberation. Libu Ntodea reflects the dialogical process that occurs in the community in determining or resolving a problem. This value also shows the characteristics of the Kaili people that are very democratic, upholding the principle of togetherness.

Ahda Najamuudin further explained that the Ntodea holiday is a forum for consensus to discuss some problems in Palu City's community, both related to social, economic, political, and religious matters. During the Ntodea holiday, several figures were present from various groups. Honor from the government, religious leaders, traditional leaders, students, NGO institutions, and community elements who have an interest. All issues will be discussed together to create a formula as a collective agreement that must be accepted and implemented by all elements of society.

Libu Ntodea, in the context of other communities, is a means of exchanging opinions or aspirational nets for the community on specific issues. However, in the context of the Kaili community, the container becomes a very functional social structure in everyday life. It is not just a symbol. Libu Ntodea is routinely held either on a large scale carried out by the Palu city government or on a small scale at the village level. Deliberation of consensus (libu ntodea) is needed in society to maintain harmony in living together. Deliberations for consensus in the Kaili community are usually held in a meeting place called baruga/bantaya.

\section{Tonda Talusi}

Tonda means furnace, talus means three supports. Tonda Talusi describes a harmonious relationship between humans, the universe and God. Nilia is still a translation from Sintuvu, which emphasizes togetherness. In its development contribution, Tonda Talusi simultaneously illustrates that the harmony of society is supported by three supports, namely, the government, traditional leaders, and religious shops. The three units are a significant force to create a balanced life. (Septiwiharti, 2020) According to Ismail, these three components are the key to the harmony that has occurred so far in Palu City. The synergy between the government through the security forces, religious leaders represented by the Indonesian Ulema Council (MUI), and traditional leaders as a force for the Palu community (interview, 12/03/2021).

These are some of the noble values that become the tight grip of the people in Palu City. In principle, these values translate the sintuvu concept that reflects harmony, kinship, the spirit of sharing, solidarity, deliberation and consensus, responsibility, and openness. In addition, there are still many slogans born in the community, such as Kitorang samua basudara, Rasa Risi Roso Nosimpotobe (one heart). These slogans invite each other to build a peaceful and harmonious society, with the principles of mutual respect, respect, and cooperation in achieving a human civilization full of compassion.

The principles of togetherness in Tonda Talusi's philosophy include three pillars of Kaili society's life based on the values of kindness, namely: 1) Matuvu Mosipeili means to see, 2) Matuvu Mosiepe means to listen, 3) Matuvu Mosimpotove means love. Tonda Talusi describes the three pillars of life in the Kaili community.

\section{Local Wisdom as The Basis for Best Practice of Religious Harmony}

The local wisdom of the people of Palu not only functions to maintain togetherness and cooperation in the community but also becomes the basis for best practices in the construction of houses of worship. The forms of implementation of local wisdom as the basis for best practice appear in two forms: first, through building houses of worship based on local wisdom; second, through the motto of life that animates all community activities; third, through traditional institutions.

First, the most interesting part of the findings is that the Vihara Karuna Dipa house of worship located in Nunu has a powerful nuance of local wisdom. The house of worship is designed to blend three cultural treasures from three different ethnicities, namely Chinese, Javanese and Kaili cultures. The front of the gate is a stupa imitating the 
Borobudur temple as a representative of Java. Meanwhile, the house of worship on the outside is designed with style and nuances of the Kaili house as a symbol of appreciation from the local community (interview, 04/03/2021).

This phenomenon is an adaptation and acculturation effort undoubtedly exciting shown by the leaders and founders of the Vihara house of worship. In turn, making local wisdom an integral part of the house of worship makes people feel belonging. In this context, the value of Ada Nosobolai (openness attitude) finds its relevance. The Buddhist community as immigrants in the Land of Kaili respects local customs; simultaneously, the Kaili community, in general, accepts the presence of new people with complete openness.

The ability of Buddhists to uphold local wisdom and merge it into wisdom through the arts becomes the strength and character inherent in Buddhist teachings. Art is a part of religious rituals. For people who have a sense of symbol language, every life experience can be religious and sacred experiences. Art Buddha is an art that contains values with the characteristics of a Buddha that can change his life into a perfect human being and behavior. In order to produce Buddhist art, it is necessary for an artist who has the vision and depth of understanding the Buddha dhamma so that his art can open up Buddhist religious horizons.

Second, through life's motto, which is internalized in society, both through education and naturally occurring culturally. It is undeniable that local wisdom such as sintuvu, nasorara nasobatutu, libu ntodea, tonda talusi is powerful in the community. As Warsana said, one of the things that pushed the openness of the Karuna Dipa school to all religions and ethnicities was because it departed from the views of our fellow adherents (interview, 05/03/2021).

Internalization of the values of harmony Internalization of the values of harmony through the life motto of the Kaili people occurs through the educational process directly and culturally. Internalization through education occurs and is institutionalized in one school rule, including traditional clothing and a stand-by for all students once a week, namely Thursday afternoon. This rule has been in effect since the mayor, Drs. Hidayat, M.S.i, leads the city of Palu, which is very well known for its attention to the preservation of local wisdom and its desire to revive these cultural symbols in the context of the wider community.

Third, traditional institutions. A genuine effort from the Palu city government to maintain the preservation of customs while increasing its function in maintaining harmony and security in the community is the strengthening of traditional institutions. Customary institutions are government partner institutions that function to empower, preserve, and develop customs. Under certain conditions, customary institutions function as guardians and implementers of customary law for people who violate existing social norms. All violations that occur in the community, such as conflicts that occur either because of social problems or religious issues, are resolved at the level of customary institutions before being handed over to the security forces. The security forces themselves have given cert ain powers to customary institutions to resolve existing problems and conflicts. Customary institutions are considered the most understanding and close to the community, so that conflict resolution through the libu Ntodea deliberation can be accepted by all parties.

\section{CLOSING}

Based on the elaboration, it can be concluded several important points as follows: First, the Vihara house of worship in Palu city received positive support from the surrounding community. This is due to the fulfillment of the administrative process and the ability of cultural adaptations carried out by Hindus and religious leaders with the local community. Buddhists carry out three best practices to maintain harmony between religious communities: multicultural education, mutual respect for worship, and cooperation in social society.

Second, the values of local wisdom that become the basis of best practice in building a temple as a house of worship are divided into two forms. First, the construction of the monastery house of worship was designed with a very thick style with a blend of Chinese, Javanese and Kaili cultures. It reflects the historical aspect and respect for local culture. Second, local wisdom as the basis for best practice through life mottos that become social tools, such as the Sintuvu culture, Nasorara Nosabatutu, Ada Nasobolai,Libu Ntodea, and Tonda Talosi. 
Third, the government's role in creating the best practice of inter-religious harmony can be seen through the presence of FKUB, which has excellent programs, such as goodwill for harmony, village harmony, and sermons on harmony technical guidance for traditional stakeholders. The resolution of conflicts in the community is resolved by sitting down with three essential elements; government, religious leaders, and traditional leaders.

In line with these conclusions, this study recommends several things:

First, it is necessary to increase positive communication through joint activities between community members, both socially and religiously. Second, the preservation of local culture that becomes social cohesion in the community urgently needs to be strengthened through the internalization process, both in academic, social, and religious activities. Third, the government needs to strengthen the role of more functional traditional institutions in maintaining religious harmony.

\section{ACKNOWLEDGEMENT}

The researchers would like to thank the Head of the Religious Research and Development Agency of Makassar for instructing a duty in Palu City. Likewise, the researcher thank Prof. Dr. Abd Kadir Ahmad, who has directed and provided guidance step by step sincerely in the research completion process. The researchers also thank all informants who cannot be acknowledged individually for their assistance and participation in the process of field data collection.

\section{REFERENCES}

A. Riyadi. (2017). Kearifan Lokal Tradisi Nyadran Lintas Agama di Desa KayenJuwangi Kabupaten Boyolali. Smart, 03, 139-154.

Abadi, M. (2012). Islam, Budaya Lokal, dan Kedewasaan Berbangsa. KARSA: Journal of Social and Islamic Culture, 13(1), 1-5.

Adon, N. J. (2018). Konflik dan integrasi pendirian rumah ibadah di kota bekasi. $S$ o c i o-Poli Ti c A, 8, 227-238.
Ahmad, N. (2013). Pesan Dakwah Dalam Menyelesaikan Konflik Pembangunan Rumah Ibadah (Kasus Pembangunan Rumah Ibadah Antara Islam dan Kristen Desa Payaman). Fikrah, 1(2), 335-364.

Fajarini, U. (2014). Peranan Kearifan Lokal Dalam Pendidikan Karakter. SOSIO DIDAKTIKA: Social Science Education Journal, https://doi.org/10.15408/sd.v1i2.1225

Fidiyani, R. (2016). Dinamika pembangunan rumah ibadah bagi warga minoritas di Jawa Tengah. Jurnal Unisbank, 501510.

Figure, S. (2015). Problematika Pendirian Rumah Ibadah Dalam di Jawa Tengah. In Sulaiman (Ed.) (pp. 1-4). Semarang: Balai Penelitian dan Pengembangan Agama Semarang.

Ibrahim, S. (2017). Efektivitas Kebijakan Pelaksanaan Kerukunan Umat Beragama. Al-Mishbah | Jurnal Ilmu Dakwah Dan Komunikasi, 12(1), 43. https://doi.org/10.24239/almishbah.vol12.iss 1.66

Islam, P., \& Boalemo, D. I. (2017). Alkhairaat dalam pengembangan pendidikan islam di boalemo, 3, 145-158.

Muhdina, D. (2015). Kerukunan Umat Beragama Berbasis Kearifan Lokal Di Kota Makassar. Jurnal Diskursus Islam, 3(1), 20-36.

Nuruddin, S. (2016). Merawat Kerukunan Dengan Kearifan Lokal Di Kabupaten Muna Sulawesi Tenggara. Al-Qalam, 21(2), 203. https://doi.org/10.31969/alq.v21i2.239

Putri, N. S. (2011). Pelaksanaan Kebebasan Beragama Di Indonesia (External Freedom) Dihubungkan Ijin Pembangunan Rumah Ibadah. Jurnal Dinamika Hukum, 11(2). https://doi.org/10.20884/1.jdh.2011.11.2 .183

Saprillah, S. (2016). Penyuluh Agama Dan Isu Kerukunan Antar Umat Beragama Di Kota Palu (Religiuos Educator and the Issue of Inter-Religious Harmony in Palu City). Al-Qalam, 22(2), 152-166.

Septiwiharti, D. (2020). Budaya Sintuvu Masyarakat Kaili Di Sulawesi Tengah, 14(1), 47-64. https://doi.org/10.2483/nw.v14.i1.419 
Takdir, M. (2018). Potret Kerukunan Berbasis Kearifan Lokal: Implementasi NilaiNilai Harmoni Dalam Ungkapan"Rampak Naong Bringen Korong” Dalam Kehidupan Masyarakat Madura. Khazanah: Jurnal Studi Islam Dan Humaniora, 16(1), 73. https://doi.org/10.18592/khazanah.v16i 1.2057
Weeks, D. P. C. C. L. E. Y. N. to K. in 20. (2015). Peraturan Bersama Menteri Agama Dan Menteri Dalam Negeri. Dk, 53(9), 1689-1699.

Widjanarko, M. (2017). Revitalisasi toleransi beragama berbasis kearifan lokal. (D. B. S. dan M. Widjanarko, Ed.). Universitas Katolik Soegijapranata. 